\title{
Dietary whey protein increases liver and skeletal muscle glycogen levels in exercise-trained rats
}

\author{
Masashi Morifuji ${ }^{1,2}$, Kensuke Sakai ${ }^{1,2}$, Chiaki Sanbongi ${ }^{1,2}$ and Katsumi Sugiura ${ }^{2}$ \\ ${ }^{1}$ Meiji Seika Kaisha Ltd., Health and Bioscience Laboratories and \\ ${ }^{2}$ Meiji Seika Kaisha Ltd., SAVAS Sports and Nutrition Laboratory, 5-3-1 Chiyoda, Sakado-shi, Saitama 350-0289, Japan
}

(Received 1 July 2004 - Revised 2 November 2004 - Accepted 19 November 2004)

\begin{abstract}
We investigated the effect of different types of dietary protein on glycogen content in liver and skeletal muscle of exercise-trained rats. Twenty-four male Sprague-Dawley rats (approximately $100 \mathrm{~g} ; n 6$ per group) were divided into sedentary or exercise-trained groups with each group being fed either casein or whey protein as the source of dietary protein. Rats in the exercised groups were trained during 2 weeks using swimming exercise for $120 \mathrm{~min} / \mathrm{d}, 6 \mathrm{~d} / \mathrm{week}$. Exercise training resulted in an increase in the skeletal muscle glycogen content. Furthermore, the whey protein group significantly increased the skeletal muscle glycogen content compared with the casein group. The increase in glycogen content in liver was significantly greater in rats fed the whey protein diet compared with those fed the casein diet. We also found that the whey protein diet increased the activity of liver glucokinase, whereas it decreased the activities of 6-phosphofructokinase and pyruvate kinase compared with the casein diet. However, hepatic total glycogen synthase activity and mRNA expression were similar with the two diets. In the skeletal muscle, whey protein decreased only 6-phosphofructokinase activity compared with casein. Total glycogen synthase activity in the skeletal muscle in the whey protein group was significantly higher than that in the casein group. The present study is the first to demonstrate that a diet based on whey protein may increase glycogen content in liver and skeletal muscle of exercise-trained rats. We also observed that whey protein regulated glycogen metabolism in these two tissues by different mechanisms.
\end{abstract}

Whey protein: Glycogen: Glycoregulatory enzymes: Exercise-trained rats

During both sprint and prolonged endurance exercise, the body must carefully balance the availability and fuel utilization in liver and skeletal muscle. In the liver, several important pathways play a role in the control of glucose homeostasis by maintaining a balance between glucose uptake and storage that is determined by glucogenesis and glycolysis, and glucose release that is determined by glycogenolysis and gluconeogenesis (Levine \& Haft, 1970). Glycolysis also has a role in determining the activity of key enzymes of the opposing glycolytic and gluconeogenic pathways, which must be controlled and regulated in order to achieve a net flux in the appropriate direction. Glycolysis shares almost all of the enzymes of the gluconeogenic pathway, except for pyruvate kinase, 6-phosphofructokinase and hexokinase/glucokinase. These three reactions of glycolysis proceed with a large negative free energy change and are bypassed during gluconeogenesis using different enzymes.

In skeletal muscle, glucose transport and glycogen synthase activity are considered the key regulatory factors for glycogen synthesis (Bogardus et al. 1984; Cartee et al. 1989) with defects in GLUT4 and hexokinase, two major components of skeletal muscle carbohydrate metabolism, being linked to insulin resistance (Shepherd \& Kahn, 1999). Exercise training in rats has been shown to increase GLUT4 (Neufer \& Dohm, 1993; Ren et al. 1994; Kuo et al. 1999) and hexokinase II gene expression and protein levels (O'Doherty et al. 1994, 1996). The major fate of skeletal muscle glucose uptake during the post-exercise period is storage as muscle glycogen, the magnitude of which correlates with the levels of skeletal muscle GLUT4 and glycogen synthase activity (McCoy et al. 1996). Glycogen depletion in the post-exercise period has been associated with enhanced insulin action, while reversal of glucose transport following exercise is correlated with muscle glycogen levels (Richter et al. 1982). Depletion of glycogen stores has been associated with fatigue during both sprint and endurance exercise (Hermansen et al. 1967; Karlsson \& Saltin, 1971; Terjung et al. 1974) and therefore it is important to maintain adequate stores of glycogen in tissues.

It is recognized that dietary carbohydrate is an effective source for tissue glycogen. Furthermore, recent studies showed that combination of carbohydrate and protein was more effective than carbohydrate alone in the replenishment of muscle glycogen during the $4 \mathrm{~h}$ immediately after exercise (Zawadzki et al. 1992; Ivy et al. 2002). However, it is not clear if different types of dietary protein affect glycogen content or the activity of glycoregulatory enzymes in tissues. Casein and whey protein are used mainly as the source of protein in dietary supplements. Accordingly, the aim of the present study was to compare the effect of casein and whey protein as the source of dietary protein on the content 
of glycogen, activity of glycoregulatory enzymes and mRNA expression in the liver and skeletal muscle of exercise-trained rats.

\section{Materials and methods}

\section{Animals}

Male Sprague-Dawley rats (CLEA Japan Inc., Tokyo, Japan) were used in this study. All the rats were housed individually in temperature-controlled rooms $\left(22^{\circ} \mathrm{C}\right)$, with light from 08.00 to 20.00 hours and dark from 20.00 to 08.00 hours. The study was approved by the Animal Committee of Meiji Seika Kaisha Ltd, Health \& Bioscience Laboratories, with the animals receiving care under the guidelines laid down by this committee.

\section{Diets}

The design of the experimental diets followed the AIN-93 protocol (Reeves et al. 1993) with the composition of the diets shown in Table 1. Casein and whey protein were used as the source of dietary protein. The protein content calculated as $\mathrm{N}$ concentration $\times 6.38$ was measured using the Kjeldahl method. Casein $(87.7 \mathrm{~g}$ crude protein $/ 100 \mathrm{~g})$ and whey protein $(79.3 \mathrm{~g}$ crude protein $/ 100 \mathrm{~g}$ ) were added as $200 \mathrm{~g}$ protein per $1 \mathrm{~kg}$ to the diets. The difference in the protein content between the two diets was compensated for by the addition of corn starch.

\section{Experimental protocol}

Twenty-four male Sprague-Dawley rats ( $n 6$ per group), each with a body weight of about $100 \mathrm{~g}$ were allowed free access to food and water for 2 weeks. The rats were then divided into sedentary or exercise-trained groups and were fed either the casein or whey protein diet. Rats in the exercise-trained groups swam simultaneously without a load $6 \mathrm{~d} /$ week for $120 \mathrm{~min} / \mathrm{d}$ in a barrel filled with water maintained at $35^{\circ} \mathrm{C}$ to a depth of $50 \mathrm{~cm}$ so that the average surface area available to each animal was $170 \mathrm{~cm}^{2}$. At the end of the 2 weeks of training, $15 \mathrm{~h}$ after the end of the last training session, all the rats were fasted for $3 \mathrm{~h}$. Holness \& Sugden (1989) showed that fasting for $3 \mathrm{~h}$ does not affect the glycogen content in tissues. The rats were killed between 09.00 and 10.00 hours. Arteriovenous blood samples were collected from all the animals under ether anaesthesia, centrifuged at $3000 \mathrm{~g}$ for $15 \mathrm{~min}$ and the serum then stored at $-80^{\circ} \mathrm{C}$.

Table 1. Composition of the two protein diets ( $\mathrm{g} / \mathrm{kg}$ diet)

\begin{tabular}{lcc}
\hline & Casein & Whey protein \\
\hline Casein* $^{*}$ & 228 & - \\
Whey protein† & - & 252 \\
Vitamin mixture & 10 & 10 \\
Choline bitartrate§ & $2 \cdot 5$ & $2 \cdot 5$ \\
Mineral mixture & 35 & 35 \\
Corn oill & 70 & 70 \\
Corn starch & $504 \cdot 5$ & $480 \cdot 5$ \\
Sucrose & 100 & 100 \\
Cellulose†† & 50 & 50
\end{tabular}

* Oriental Yeast Co. Ltd, Tokyo, Japan.

† Nihon NZMP Co. Ltd, Tokyo, Japan.

$\ddagger$ AIN-93 diet, Nosan Corporation, Kanagawa, Japan.

$\S$ Wako Pure Chemical Industries Ltd, Osaka, Japan.

$\|$ Ajinomoto Co. Inc., Tokyo, Japan.

I Taiyo Kagaku Co. Ltd, Mie, Japan.

**Nippon Beet Sugar Manufacturing Co. Ltd, Tokyo, Japan.

††Asahi Kasei Corporation, Tokyo, Japan.
After blood collection, the abdominal cavity was opened and the liver and gastrocnemius muscle were quickly excised, washed, weighed and frozen at $-80^{\circ} \mathrm{C}$ until assay.

\section{Serum analyses}

Serum glucose concentration was measured using a glucose oxidase assay (Miwa et al. 1972), serum insulin concentration by an ELISA kit obtained from Mercodia AB (Uppsala, Sweden) and serum glucagon level by an ELISA kit purchased from Wako Pure Chemical Industries Ltd (Osaka, Japan).

\section{Glycogen analysis}

Tissue glycogen was isolated and purified by precipitation with ethanol from a digest formed by the addition of $5 \cdot 3 \mathrm{M}-\mathrm{KOH}$, and then quantified by the phenol-sulphuric acid method (Lo et al. 1970).

\section{Enzyme activities}

Aliquots of liver or skeletal muscle were homogenized in $0 \cdot 1$ $\mathrm{M}$-Tris- $\mathrm{HCl}$ buffer ( $\mathrm{pH}$ 7.4) using a Potter-Elvhjem-type homogenizer fitted with a Teflon pestle. The homogenate was centrifuged for $30 \mathrm{~min}$ at $12000 \mathrm{~g}$ at $4^{\circ} \mathrm{C}$ and the supernant was used immediately to determine the enzyme activities.

Glucokinase (EC 2.7.1.1), hexokinase (EC 2.7.1.1), 6-phosphofructokinase (EC 2.7.1.11) and pyruvate kinase (EC 2.7.1.40) were assayed spectrophotometrically. Glucokinase was assayed according to Grossman et al. (1974) with the assay mixture containing 0.1 M-Tris- $\mathrm{HCl}$ (pH 7.5), $5 \mathrm{~mm}-\mathrm{MgCl}_{2}, 5 \mathrm{~mm}-\mathrm{ATP}$, $100 \mathrm{~mm}$-glucose, $0.4 \mathrm{~mm}$-NADP and $0.3 \mathrm{U}$ glucose 6 -phosphate dehydrogenase. Hexokinase was assayed according to Burcelin et al. (1993) using an assay mixture containing $0 \cdot 1 \mathrm{M}-\mathrm{Tris}-\mathrm{HCl}$

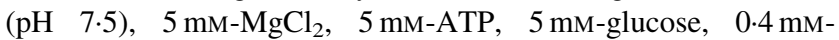
NADP and $0.3 \mathrm{U}$ glucose 6-phosphate dehydrogenase. The method of Karadsheh et al. (1977) was used to analyse 6-phosphofructokinase activity with the assay mixture containing $50 \mathrm{~mm}$-Tris- $\mathrm{HCl}$ ( $\mathrm{pH} 8.2$ ), $1 \mathrm{~mm}$-fructose 6-phosphate, $1 \mathrm{~mm}$ ATP, $\quad 0.16 \mathrm{~mm}-\mathrm{NADH}, \quad 1 \mathrm{~mm}$-EDTA, $2.5 \mathrm{~mm}$-dithiothreitol, $2 \mathrm{mM}-\mathrm{MgCl}_{2}, 5 \mathrm{mM}$-ammonium sulphate, $0.4 \mathrm{U}$ aldolase, $2.4 \mathrm{U}$ triosephosphate isomerase and $0.4 \mathrm{U}$ glycerophosphate dehydrogenase. Pyruvate kinase was determined according to the method described by Harada et al. (1978) using an assay mixture containing $50 \mathrm{~mm}-\mathrm{Tris}-\mathrm{HCl}(\mathrm{pH} \mathrm{7.5}), 100 \mathrm{~mm}-\mathrm{KCl}$,

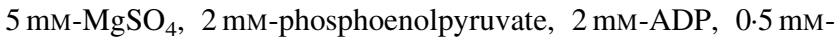
fructose 1,6-bisphosphate, $0 \cdot 18 \mathrm{~mm}-\mathrm{NADH}$ and $8 \mathrm{U}$ lactate dehydrogenase. Total glycogen synthase activity (EC 2.4.1.11) was measured by the method of Danforth (1965) with enzyme activity assayed at $\mathrm{pH} 7.4$ and $30^{\circ} \mathrm{C}$ in a reaction mixture containing $60 \mathrm{~mm}$-Tris- $\mathrm{HCl}$ (pH 7.4), 1.2 mM-EDTA, 3 mM-mercaptoethanol, $1.2 \mathrm{~mm}-\mathrm{NaF}, 7.5 \mathrm{~mm}$-UDP-glucose and $1.2 \%$ (w/v) glycogen. The assay was carried out in the presence of $12 \mathrm{mM}$-glucose 6-phosphate in order to measure total glycogen synthase activity with the reaction being terminated by heating for $2 \mathrm{~min}$ in a boiling water-bath. The denatured protein was removed by centrifugation and UDP concentration in the supernatant solution assayed enzymatically by allowing UDP to react with phosphoenolpyruvate in the presence of pyruvate kinase.

The total protein concentration of the tissue homogenate supernatant was measured using bicinchoninic acid with bovine serum albumin as the standard (Smith et al. 1985). 


\section{Total RNA isolation and cDNA}

Total RNA was isolated from the liver and skeletal muscle by the guanidine thiocyanate method of Chomczynski \& Sacchi (1987) using Isogen solution (Nippon Gene Co. Ltd, Tokyo, Japan). The extracted RNA was dissolved in diethylpyrocarbonate-treated water and quantified spectrophotometrically at a wavelength of $260 \mathrm{~nm}$. Reverse transcription was used to produce cDNA from RNA using a first standard cDNA synthesis kit (Fermentas Inc.). The cDNA was stored at $-80^{\circ} \mathrm{C}$ for subsequent analysis.

\section{Quantitative real-time $R T-P C R$ analysis}

Real-time PCR was performed using the ABI PRISM 7000 sequence detection system (Applied Biosystems). Primers and probes (TaqMan ${ }^{\circledR}$ Assays-on-Demand ${ }^{\mathrm{TM}}$ Gene Expression Products) were designed at Applied Biosystems (Foster City, CA, USA) from gene sequences obtained from GenBank (GLUT2, NM-012879; glycogen synthase II, NM-013089; glucokinase, NM-012565; GLUT4, NM-012751; hexokinase, NM-012735; glycogen synthase I, XM-341858). DNA amplification was carried out in $12.5 \mu \mathrm{l}$ TaqMan Universal PCR Master Mix, 1.25 $\mu \mathrm{l}$ primer and probes, $2.5 \mu \mathrm{l}$ cDNA and $8.75 \mu \mathrm{l}$ RNase and DNase free water in a final volume of $25 \mu \mathrm{l} /$ well. The samples were loaded in a MicroAmp 96-well reaction plate and then run using the $\mathrm{ABI}$ sequence detection system. After $2 \mathrm{~min}$ at $50^{\circ} \mathrm{C}$ and $10 \mathrm{~min}$ at $95^{\circ} \mathrm{C}$, the plates were co-amplified by 50 repeated cycles, with each cycle consisting of a $30 \mathrm{~s}$ denaturing step at $95^{\circ} \mathrm{C}$ and a 1 min annealing/extending step at $59^{\circ} \mathrm{C}$. Data were analysed by ABI software using the cycle threshold $\left(\mathrm{C}_{\mathrm{T}}\right)$, a value that is calculated as the time, measured as cycle number, at which the reporter fluorescent emission increased beyond a threshold level, defined as the background number at which cDNA amplification was first detected. Fluorescent emission data were captured and mRNA levels quantified for each gene using the $\mathrm{C}_{\mathrm{T}}$ value. The $\Delta \mathrm{C}_{\mathrm{T}}$ was calculated by subtracting the $\mathrm{C}_{\mathrm{T}}$ for $\beta$-actin from the $C_{T}$ for the gene of interest. The relative expression of the gene of interest was then calculated using the expression $2^{-\Delta \mathrm{CT}}$ with the results being expressed as arbitrary units.

\section{Statistics}

Data were subjected to two-way ANOVA with post hoc analyses being carried out by Tukey's honestly significant difference test.
Associations between the variables were examined using Pearson's correlation coefficient. Differences between groups were considered to be significant at $P<0 \cdot 05$.

\section{Results}

Initial body weight, food intake and body weight gain

Table 2 shows the changes in initial body weight, food intake, body weight gain and liver and gastrocnemius muscle weights. Food intake and body weight gain were not different between the casein and the whey protein diets. Exercise training for 2 weeks significantly decreased the gain in body weight. The liver weight was significantly higher in the whey protein group compared with the casein group.

\section{Serum glucose, insulin and glucagon}

Serum glucose and serum insulin levels were significantly lower in the exercise training groups compared with the sedentary groups. However, serum glucagon level was not affected by exercise training. Fig. 1 shows that the type of dietary protein had no effect on the serum levels of glucose, insulin or glucagon.

\section{Liver and skeletal muscle glycogen}

Liver glycogen content in the whey protein groups was increased significantly compared with the casein groups. Rats receiving exercise training had significant increases in the glycogen content of skeletal muscle compared with sedentary animals. The level of skeletal muscle glycogen in the whey protein group was also higher than levels in the casein group (Fig. 2).

\section{Liver glycoregulatory enzyme activities}

Glucokinase activity was increased significantly in the whey protein groups compared with the casein groups. In contrast, the groups fed whey protein significantly lowered pyruvate kinase and 6-phosphofructokinase activities compared with the groups fed casein. Exercise training decreased pyruvate kinase activity, but had no effect on glucokinase or 6-phosphofructokinase activity. Hepatic total glycogen synthase activity was similar in all the groups (Table 3).

Table 2. Initial body weight, food intake and body weight gain

(Mean values with their standard errors)

\begin{tabular}{|c|c|c|c|c|c|c|c|c|c|c|}
\hline \multirow[b]{2}{*}{ Group } & \multicolumn{2}{|c|}{ Initial body wt $(\mathrm{g})$} & \multicolumn{2}{|c|}{$\begin{array}{l}\text { Food intake } \\
\qquad(g / 14 d)\end{array}$} & \multicolumn{2}{|c|}{$\begin{array}{l}\text { Body wt gain } \\
\quad(g / 14 d)\end{array}$} & \multicolumn{2}{|c|}{$\begin{array}{l}\text { Liver wt }(\mathrm{g} / 100 \mathrm{~g} \\
\text { body wt) }\end{array}$} & \multicolumn{2}{|c|}{$\begin{array}{l}\text { Gastrocnemius } \\
\text { muscle wt } \\
\text { (g/100 g body wt) }\end{array}$} \\
\hline & Mean & SE & Mean & SE & Mean & SE & Mean & SE & Mean & SE \\
\hline Sedentary - casein & 101 & 2 & 257 & 5 & 114 & 3 & 4.98 & $0 \cdot 18$ & 1.06 & 0.02 \\
\hline Sedentary - whey protein & 101 & 1 & 240 & 7 & 111 & 2 & $5 \cdot 41$ & 0.15 & $1 \cdot 10$ & 0.02 \\
\hline Exercise-trained - casein & 99 & 2 & 249 & 5 & 104 & 2 & $4 \cdot 66$ & 0.09 & 1.09 & 0.02 \\
\hline $\begin{array}{l}\text { Exercise-trained - whey protein } \\
\text { Two-way ANOVA }\end{array}$ & 99 & 2 & 240 & 4 & 101 & 3 & $5 \cdot 19$ & $0 \cdot 12$ & 1.04 & 0.02 \\
\hline Diet & 0.990 & & 0.081 & & 0.896 & & 0.003 & & 0.777 & \\
\hline Exercise & 0.166 & & 0.785 & & $<0.001$ & & 0.070 & & 0.689 & \\
\hline Diet $\times$ exercise & 0.876 & & 0.479 & & 0.252 & & 0.690 & & 0.052 & \\
\hline
\end{tabular}


(a)

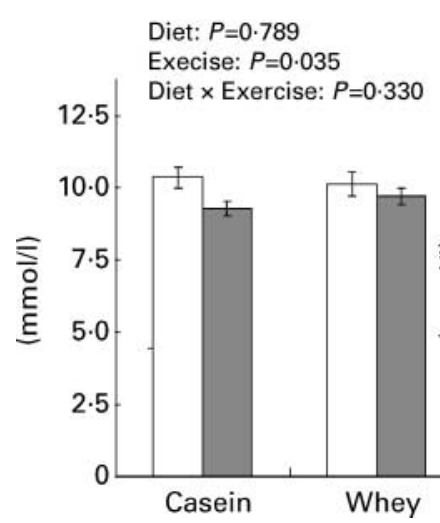

(b)

Diet: $P=0.996$ Execise: $P=0.001$

Diet $\times$ Exercise: $P=0.081$ (c)

Diet: $P=0.805$

Execise: $P=0.108$

Diet $\times$ Exercise: $P=0.387$

Fig. 1. Effect of dietary protein on (a) serum glucose, (b) serum insulin and (c) serum glucagon concentrations in sedentary ( $\square$ ) or exercise-trained ( $\square$ ) rats. Values are means with their standard errors depicted by vertical bars.

\section{Liver $m R N A$ levels}

A significant decrease in hepatic GLUT2 mRNA levels was observed in exercise training rats compared with sedentary rats, whereas glucokinase and glycogen synthase I mRNA levels did not vary among the groups (Table 4).

\section{Skeletal muscle glycoregulatory enzyme activities}

Hexokinase and total glycogen synthase activities were higher in exercise training rats than in sedentary rats. In contrast, 6-phosphofructokinase and pyruvate kinase activities were not altered by exercise training. However, groups fed whey protein had increased total glycogen synthase activity and decreased 6-phosphofructokinase activity compared with the groups fed casein (Table 5).

\section{Skeletal muscle mRNA levels}

While exercise training resulted in a significant increase in mRNA levels of GLUT4, hexokinase II and glycogen synthase I, the type of dietary protein had little effect on mRNA expression of these enzymes (Table 6).

\section{Discussion}

Depletion of glycogen stores has been associated with fatigue during both sprint and endurance exercise (Hermansen et al. 1967; Karlsson \& Saltin, 1971; Terjung et al. 1974). Storage of glycogen in tissues is therefore of great importance, with dietary carbohydrate being the main source of tissue glycogen. However, it is not clear if different types of dietary protein affect glycogen content or the activity of glycoregulatory enzymes in tissues. The present study showed for the first time that the type of dietary protein affects both liver and muscle glycogen content, as exercise-trained rats fed a whey protein diet were shown to accumulate more glycogen than those fed a casein diet.

Control of hepatic glycogen storage is governed by two related pathways, namely glycogen metabolism that incorporates both synthesis and degradation, gluconeogenesis and glycolysis, the latter pathway essentially being a reversal of gluconeogenesis. The same enzymes catalyse glycolysis and gluconeogenesis except at three (a)

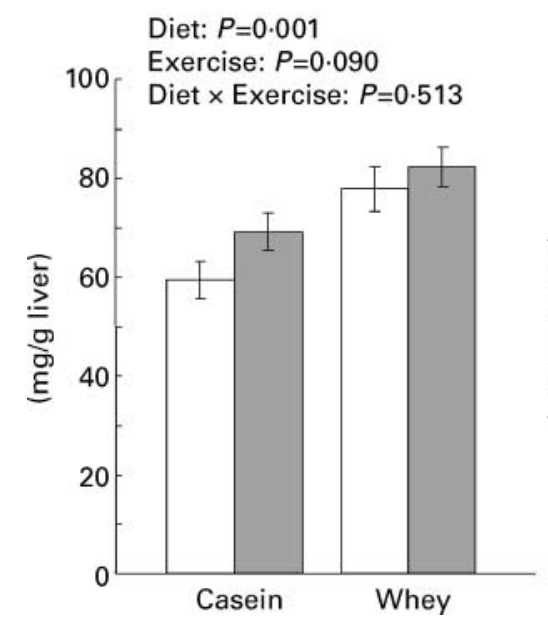

(b)

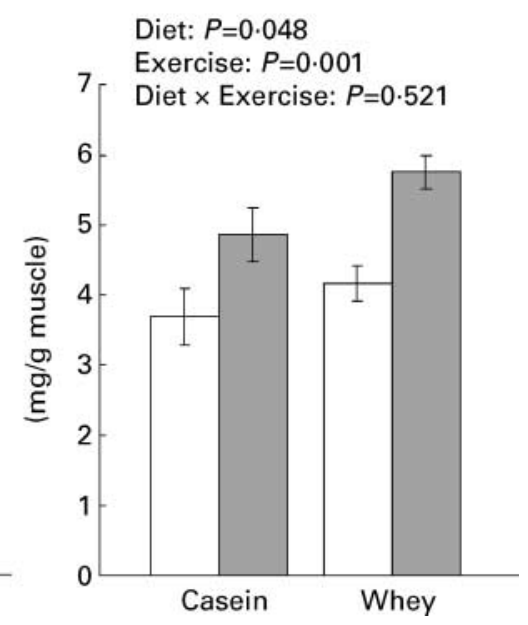

Fig. 2. Effect of dietary protein on (a) liver and (b) gastrocnemius muscle glycogen content in sedentary ( $\square$ ) or exercise-trained ( $\square$ ) rats. Values are means with their standard errors depicted by vertical bars. 
Table 3. Liver glycoregulatory enzyme activities

(Mean values with their standard errors)

\begin{tabular}{|c|c|c|c|c|c|c|}
\hline \multirow[b]{2}{*}{ Group } & \multicolumn{2}{|c|}{ Glucokinase* } & \multicolumn{2}{|c|}{ 6-Phosphofructokinase ${ }^{\star}$} & \multicolumn{2}{|c|}{ Pyruvate kinase* } \\
\hline & Mean & SE & Mean & SE & Mean & SE \\
\hline Sedentary - casein & $65 \cdot 0$ & 7.5 & $11 \cdot 6$ & 0.7 & 687 & 37 \\
\hline Sedentary - whey protein & 98.7 & $4 \cdot 3$ & 9.8 & 0.7 & 527 & 18 \\
\hline Exercise-trained - casein & $66 \cdot 4$ & $5 \cdot 2$ & $12 \cdot 6$ & 0.3 & 584 & 44 \\
\hline Exercise-trained - whey protein & 84.5 & $6 \cdot 8$ & $9 \cdot 6$ & 0.4 & 383 & 23 \\
\hline \multicolumn{7}{|l|}{ Two-way ANOVA } \\
\hline Diet & $<0.001$ & & 0.001 & & $<0.001$ & \\
\hline Exercise & 0.305 & & 0.226 & & 0.002 & \\
\hline Diet $\times$ exercise & 0.214 & & 0.125 & & 0.564 & \\
\hline
\end{tabular}

${ }^{*}$ Data are expressed in $\mathrm{nmol} / \mathrm{min}$ per $\mathrm{mg}$ protein.

regulated sites that involve either glucokinase or glucose 6-phosphatase, phosphofructokinase or fructose 1,6-bisphosphatase and pyruvate kinase or phosphoenolpyruvate carboxykinase. These ratelimiting enzymes are therefore of great importance as they occupy key positions in carbohydrate metabolism. We demonstrated in groups fed whey protein that hepatic glucokinase activity was increased and 6-phosphofructokinase and pyruvate kinase activities decreased compared with casein-fed groups. However, total glycogen synthase was not affected by either dietary protein. Recently, de la Iglesia et al. (2000) showed that glucokinase has a number of unique regulatory properties and exerts considerable control over hepatic glucose uptake and glycogen synthesis. In the present study, we observed a significant correlation $(r$ 0.53, $P=0.001)$ between hepatic glycogen level and glucokinase activity, a finding that suggests activation of glucokinase activity resulting from the whey protein diet may lead to an increase in hepatic glycogen. Furthermore, inhibition of 6-phosphofructokinase and pyruvate kinase in the whey protein groups may have conserved utilization of glucose by glycogenolysis.

The liver expresses unique proteins for the three pathways involved in glycogen storage. Glucose transport is carried out by GLUT2, a member of the facilitative glucose transporter family (Burcelin et al. 2000). The GLUT2 system moves glucose down a concentration gradient with net flux dependent on the relative intra- and extracellular glucose concentration. However, it remains unclear whether exercise training affects the hepatic levels of GLUT2. We found that exercise training caused a significant decrease in GLUT2 mRNA levels that may have been a consequence of the reduction in serum glucose concentration. In addition, we observed a significant positive correlation $(r$ 0.78, $P<0.001)$ between GLUT2 and glycogen synthase II mRNA expression. Although there was only minimal correlation between hepatic glycogen content and glycogen synthase II mRNA expression ( $r-0.249, P=0.121)$, we observed a strong negative correlation between liver glycogen content and GLUT2 mRNA level $(r-0.52, P=0 \cdot 005)$. These results indicate that regulation of hepatic glycogen resulting from a whey protein diet is dependent on modulation of glycolytic and gluconeogenic enzymes, but not on an increase in the activity of GLUT2 or glycogen synthase.

We also observed that swimming training increased the mRNA level of GLUT4, hexokinase and glycogen synthase, and the activities of hexokinase and total glycogen synthase in skeletal muscle. A number of previous studies have provided evidence that there is a relationship between skeletal muscle glycogen and glucose transport (Bogardus et al. 1984; Cartee et al. 1989; Neufer \& Dohm, 1993; O’Doherty et al. 1994, 1996; Ren et al. 1994; Kuo et al. 1999; Shepherd \& Kahn, 1999). Exercise training is known to increase GLUT4 content and improve insulin-stimulated glucose uptake, with a single exercise session having been shown to increase the rate of insulin-stimulated glucose uptake and metabolism in skeletal muscle for $24-48 \mathrm{~h}$. This increase was attributed to an effect of exercise on translocation of the GLUT4 glucose transporter (Ren et al. 1994; Phillips et al. 1996), hexokinase (O'Doherty et al. 1994, 1996) or glycogen synthase activity (Devlin et al. 1987). Moreover, skeletal muscle glycogen accumulation has been shown to correlate with the relative proportion of glycogen synthase. In the present study, dietary whey protein induced the accumulation of skeletal muscle glycogen in exercise-trained rats,

Table 4. Liver mRNA levels

(Mean values with their standard errors)

\begin{tabular}{|c|c|c|c|c|c|c|}
\hline \multirow[b]{2}{*}{ Group } & \multicolumn{2}{|c|}{ GLUT2* $^{*}$} & \multicolumn{2}{|c|}{ Glucokinase* $^{*}$} & \multicolumn{2}{|c|}{ Glycogen synthase II* } \\
\hline & Mean & SE & Mean & SE & Mean & SE \\
\hline Sedentary - casein & 100 & 11 & 100 & 20 & 100 & 5 \\
\hline Sedentary - whey protein & $84 \cdot 0$ & $7 \cdot 0$ & 115 & 34 & 103 & 7 \\
\hline Exercise-trained - casein & $81 \cdot 3$ & $6 \cdot 7$ & $90 \cdot 1$ & $15 \cdot 9$ & $96 \cdot 1$ & $6 \cdot 7$ \\
\hline Exercise-trained - whey protein & $67 \cdot 9$ & $5 \cdot 1$ & 134 & 24 & $84 \cdot 4$ & $6 \cdot 0$ \\
\hline \multicolumn{7}{|l|}{ Two-way ANOVA } \\
\hline Diet & 0.069 & & 0.247 & & 0.475 & \\
\hline Exercise & 0.034 & & 0.860 & & 0.088 & \\
\hline Diet $\times$ exercise & 0.862 & & 0.566 & & 0.256 & \\
\hline
\end{tabular}

* Data are expressed in arbitrary units. 
Table 5. Skeletal muscle glycoregulatory enzyme activities

(Mean values with their standard errors)

\begin{tabular}{|c|c|c|c|c|c|c|c|c|}
\hline \multirow[b]{2}{*}{ Group } & \multicolumn{2}{|c|}{ Hexokinase* } & \multicolumn{2}{|c|}{$\begin{array}{c}\text { 6-Phosphofruc- } \\
\text { tokinase* }\end{array}$} & \multicolumn{2}{|c|}{$\begin{array}{l}\text { Pyruvate } \\
\text { kinase } †\end{array}$} & \multicolumn{2}{|c|}{$\begin{array}{l}\text { Glycogen } \\
\text { synthase }^{*}\end{array}$} \\
\hline & Mean & SE & Mean & SE & Mean & SE & Mean & SE \\
\hline Sedentary - casein & $18 \cdot 5$ & 0.8 & $28 \cdot 7$ & $2 \cdot 1$ & $5 \cdot 67$ & $0 \cdot 13$ & $1 \cdot 28$ & 0.36 \\
\hline Sedentary - whey protein & $18 \cdot 2$ & 1.5 & $20 \cdot 9$ & $1 \cdot 0$ & $6 \cdot 02$ & 0.23 & $3 \cdot 33$ & 0.40 \\
\hline Exercise-trained - casein & $24 \cdot 6$ & 0.9 & $31 \cdot 7$ & 3.5 & 6.07 & 0.26 & $5 \cdot 11$ & 0.54 \\
\hline $\begin{array}{l}\text { Exercise-trained - whey protein } \\
\text { Two-way ANOVA }\end{array}$ & $25 \cdot 4$ & $1 \cdot 0$ & $15 \cdot 2$ & $2 \cdot 4$ & $5 \cdot 63$ & 0.20 & $6 \cdot 37$ & 0.52 \\
\hline Diet & 0.861 & & $<0.001$ & & 0.815 & & 0.002 & \\
\hline Exercise & $<0.001$ & & 0.592 & & 0.972 & & $<0.001$ & \\
\hline Diet $\times$ exercise & 0.622 & & 0.090 & & 0.075 & & 0.406 & \\
\hline
\end{tabular}

* Data are expressed in $\mathrm{nmol} / \mathrm{min}$ per $\mathrm{mg}$ protein

$\dagger$ Data are expressed in $\mu \mathrm{mol} / \mathrm{min}$ per $\mathrm{mg}$ protein.

Table 6. Skeletal muscle mRNA levels

(Mean values with their standard errors)

\begin{tabular}{|c|c|c|c|c|c|c|}
\hline \multirow[b]{2}{*}{ Group } & \multicolumn{2}{|c|}{ GLUT4* $^{*}$} & \multicolumn{2}{|c|}{ Hexokinase $\mathrm{II}^{*}$} & \multicolumn{2}{|c|}{$\begin{array}{l}\text { Glycogen } \\
\text { synthase I* }\end{array}$} \\
\hline & Mean & SE & Mean & SE & Mean & SE \\
\hline Sedentary - casein & 100 & 7 & 100 & 10 & 100 & 43 \\
\hline Sedentary - whey protein & 104 & 8 & 81 & 9 & 422 & 139 \\
\hline Exercise-trained - casein & 150 & 3 & 133 & 6 & 1019 & 220 \\
\hline $\begin{array}{l}\text { Exercise-trained - whey protein } \\
\text { Two-way ANOVA }\end{array}$ & 139 & 7 & 134 & 9 & 1270 & 433 \\
\hline Diet & 0.578 & & 0.273 & & 0.31 & \\
\hline Exercise & $<0.001$ & & $<0.001$ & & $<0.001$ & \\
\hline Diet $\times$ exercise & 0.246 & & 0.262 & & 0.889 & \\
\hline
\end{tabular}

* Data are expressed in arbitrary units

and increased glycogen synthase activity with a significant positive correlation $(r$ 0.86; $P<0.001)$ between skeletal muscle glycogen synthase and glycogen content being observed. However, we were unable to demonstrate any effect of the type of dietary protein on GLUT4 mRNA level, and hexokinase activity and mRNA expression. In contrast to liver carbohydrate metabolism, skeletal muscle pyruvate kinase activity was similar with the casein and whey protein diets, while skeletal muscle 6-phosphofructokinase activity was lower in the whey groups than in the casein groups. We also observed a significant negative correlation between skeletal muscle 6-phosphofructokinase activity and glycogen content $(r-0.37 ; P=0.036)$. Taken together these findings indicate that whey protein increases skeletal muscle glycogen content as a result of an increase in total glycogen synthase activity or a decrease in 6-phosphofructokinase activity.

The regulation of glycogenesis is also mediated by hormonal changes, especially insulin and glucagon. Zawadzki et al. (1992) reported that addition of an intact protein to a carbohydrate-containing solution resulted in higher glycogen synthesis rates in subjects after exercise than did ingestion of carbohydrate only. This was explained by the observed additional increase in plasma insulin concentrations after ingestion of the carbohydrate-protein mixture. Elevated insulin concentrations may lead to increased glucose uptake (Ivy \& Kuo, 1998) and to an increase in glycogen synthase activity (Bak et al. 1991). However, in the present study, the serum levels of glucose, insulin and glucagon were similar with the two protein diets. Despite these similarities, we found dietary whey protein increased the activity of hepatic glucokinase and skeletal muscle glycogen synthase, and decreased the activities of liver and skeletal muscle 6-phosphofructokinase compared with dietary casein. This finding implies that the effect of the whey protein diet on the activity of tissue glycolytic enzymes is not related to changes in the concentration of serum hormones.

There is evidence that certain amino acids may also stimulate glycolytic and gluconeogenic enzyme activity in liver. In isolated hepatocytes, several amino acids such as glutamine, proline, alanine and histidine have been shown to stimulate glycogen synthesis from glucose and gluconeogenic precursors (Baquet et al. 1990). Contrary to the liver, it is established that certain amino acids have an important role in glucose uptake and glycogen synthesis in skeletal muscle, as previous studies in myoblast L6 cells (Peyrollier et al. 2000) and cultured human muscle have shown that leucine and total amino acid concentration activates glycogen synthase via mammalian target of rapamycin (mTOR) activation (Armstrong et al. 2001). Furthermore, our previous report demonstrated in exercise-trained rats that a whey protein diet, compared with casein and soy protein diets, had beneficial effects on liver glycogen storage as a result of regulation of the activity of glycolytic and gluconeogenic enzymes and aminotransferase. Compared with casein, whey protein caused significant increases in the level of various amino acids, especially alanine and also enhanced hepatic alanine aminotransferase activity. This increase in alanine aminotransferase indicated enhancement of glycogenesis from alanine (Morifuji et al. 2005). In addition, the significant changes we observed in this metabolism 
in rats fed whey protein may be related to other dietary ingredients of whey protein because whey protein is not purified protein and consists of various proteins, such as $\beta$-lactoglobulin (50\%), $\alpha$-lactalbumin (25\%), serum albumin (7\%) and immunoglobulins (5\%) (Heine et al. 1991). However, the manner in which these ingredients may exert this effect is not fully understood.

In conclusion, this is the first study to show that a diet based on whey protein increases glycogen content in liver and skeletal muscle in exercise-trained rats. We consider that a daily intake of whey protein may play an important role in increasing the glycogen content of tissues in exercised-trained rats.

\section{References}

Armstrong JL, Bonavaud SM, Toole BJ \& Yeaman SJ (2001) Regulation of glycogen synthesis by amino acids in cultured human muscle cells. J Biol Chem 276, 952-956.

Bak JF, Moller N, Schmitz O, Richter EA \& Pedersen O (1991) Effects of hyperinsulinemia and hyperglycemia on insulin receptor function and glycogen synthase activation in skeletal muscle of normal man. Metabolism 40, 830-835.

Baquet A, Hue L, Meijer AJ, van Woerkom GM \& Plomp PJ (1990) Swelling of rat hepatocytes stimulates glycogen synthesis. J Biol Chem $\mathbf{2 6 5}$, 955-959.

Bogardus C, Lillioja S, Stone K \& Mott D (1984) Correlation between muscle glycogen synthase activity and in vivo insulin action in man. J Clin Invest 73, 1185-1190.

Burcelin R, del Carmen Munoz M, Guillam MT \& Thorens B (2000) Liver hyperplasia and paradoxical regulation of glycogen metabolism and glucose-sensitive gene expression in GLUT2-null hepatocytes. Further evidence for the existence of a membrane-based glucose release pathway. J Biol Chem 275, 10930-10936.

Burcelin R, Printz RL, Kande J, Assan R, Granner DK \& Girard J (1993) Regulation of glucose transporter and hexokinase II expression in tissues of diabetic rats. Am J Physiol 265, E392-E401.

Cartee GD, Young DA, Sleeper MD, Zierath J, Wallberg-Henriksson H \& Holloszy JO (1989) Prolonged increase in insulin-stimulated glucose transport in muscle after exercise. Am J Physiol 256, E494-E499.

Chomczynski P \& Sacchi N (1987) Single-step method of RNA isolation by acid guanidinium thiocyanate-phenol-chloroform extraction. Anal Biochem 162, 156-159.

Danforth WH (1965) Glycogen synthetase activity in skeletal muscle. Interconversion of two forms and control of glycogen synthesis. J Biol Chem 240, 588-593.

de la Iglesia N, Mukhtar M, Seoane J, Guinovart JJ \& Agius L (2000) The role of the regulatory protein of glucokinase in the glucose sensory mechanism of the hepatocyte. J Biol Chem 275, 10597-10603.

Devlin JT, Hirshman M, Horton ED \& Horton ES (1987) Enhanced peripheral and splanchnic insulin sensitivity in NIDDM men after single bout of exercise. Diabetes 36, 434-439.

Grossman S, Dorn C \& Potter V (1974) The preparation and characterization of pure rat liver glucokinase. J Biol Chem 249, 3055-3060.

Harada K, Saheki S, Wada K \& Tanaka T (1978) Purification of four pyruvate kinase isozymes of rats by affinity elution chromatography. Biochim Biophys Acta 524, 327-339.

Heine WE, Klein PD \& Reeds PJ (1991) The importance of alpha-lactalbumin in infant nutrition. J Nutr 121, 277-283.

Hermansen L, Hultman E \& Saltin B (1967) Muscle glycogen during prolonged severe exercise. Acta Physiol Scand 71, 129-139.

Holness MJ \& Sugden MC (1989) Pyruvate dehydrogenase activities during the fed-to-starved transition and on re-feeding after acute or prolonged starvation. Biochem J 258, 529-533.

Ivy JL, Goforth HW Jr, Damon BM, McCauley TR, Parsons EC \& Price TB (2002) Early postexercise muscle glycogen recovery is enhanced with a carbohydrate-protein supplement. J Appl Physiol 93, 1337-1344.
Ivy JL \& Kuo CH (1998) Regulation of GLUT4 protein and glycogen synthase during muscle glycogen synthesis after exercise. Acta Physiol Scand 162, 295-304.

Karadsheh NS, Uyeda K \& Oliver RM (1977) Studies on structure of human erythrocyte phosphofructokinase. J Biol Chem 252, 3515-3524.

Karlsson J \& Saltin B (1971) Diet, muscle glycogen, and endurance performance. J Appl Physiol 31, 203-206.

Kuo CH, Browning KS \& Ivy JL (1999) Regulation of GLUT4 protein expression and glycogen storage after prolonged exercise. Acta Physiol Scand 165, 193-201.

Levine R \& Haft DE (1970) Carbohydrate homeostasis. I. N Engl J Med 283, 175-183.

Lo S, Russell JC \& Taylor AW (1970) Determination of glycogen in small tissue samples. J Appl Physiol 28, 234-236.

McCoy M, Proietto J \& Hargreaves M (1996) Skeletal muscle GLUT-4 and postexercise muscle glycogen storage in humans. J Appl Physiol 80, $411-415$.

Miwa I, Okudo J, Maeda K \& Okuda G (1972) Mutarotase effect on colorimetric determination of blood glucose with D-glucose oxidase. Clin Chim Acta 37, 538-540.

Morifuji M, Sakai K \& Sugiura K (2005) Dietary whey protein modulates liver glycogen level and glycoregulatory enzyme activities in exercisetrained rats. Exp Biol Med 230, 23-30.

Neufer PD \& Dohm GL (1993) Exercise induces a transient increase in transcription of the GLUT-4 gene in skeletal muscle. Am J Physiol 265, C1597-C1603.

O’Doherty RM, Bracy DP, Granner DK \& Wasserman DH (1996) Transcription of the rat skeletal muscle hexokinase II gene is increased by acute exercise. J Appl Physiol 81, 789-793.

O'Doherty RM, Bracy DP, Osawa H, Wasserman DH \& Granner DK (1994) Rat skeletal muscle hexokinase II mRNA and activity are increased by a single bout of acute exercise. Am J Physiol 266, E171-E178.

Peyrollier K, Hajduch E, Blair AS, Hyde R \& Hundal HS (2000) L-leucine availability regulates phosphatidylinositol 3-kinase, p70 S6 kinase and glycogen synthase kinase-3 activity in L6 muscle cells: evidence for the involvement of the mammalian target of rapamycin (mTOR) pathway in the L-leucine-induced up-regulation of system A amino acid transport. Biochem J 350, Pt 2, 361-368.

Phillips SM, Han XX, Green HJ \& Bonen A (1996) Increments in skeletal muscle GLUT-1 and GLUT-4 after endurance training in humans. Am J Physiol 270, E456-E462.

Reeves PG, Nielsen FH \& Fahey GC Jr (1993) AIN-93 purified diets for laboratory rodents: final report of the American Institute of Nutrition ad hoc writing committee on the reformulation of the AIN-76A rodent diet. J Nutr 123, 1939-1951.

Ren JM, Semenkovich CF, Gulve EA, Gao J \& Holloszy JO (1994) Exercise induces rapid increases in GLUT4 expression, glucose transport capacity, and insulin-stimulated glycogen storage in muscle. $J$ Biol Chem 269, 14396-14401.

Richter EA, Garetto LP, Goodman MN \& Ruderman NB (1982) Muscle glucose metabolism following exercise in the rat: increased sensitivity to insulin. J Clin Invest 69, 785-793.

Shepherd PR \& Kahn BB (1999) Glucose transporters and insulin action implications for insulin resistance and diabetes mellitus. $N$ Engl J Med 341, 248-257.

Smith PK, Krohn RI, Hermanson GT, Mallia AK, Gartner FH, Provenzano MD, Fujimoto EK, Goeke NM, Olson BJ \& Klenk DC (1985) Measurement of protein using bicinchoninic acid. Anal Biochem 150, $76-85$.

Terjung RL, Baldwin KM, Winder WW \& Holloszy JO (1974) Glycogen repletion in different types of muscle and in liver after exhausting exercise. Am J Physiol 226, 1387-1391.

Zawadzki KM, Yaspelkis BB 3rd \& Ivy JL (1992) Carbohydrate-protein complex increases the rate of muscle glycogen storage after exercise. J Appl Physiol 72, 1854-1859. 